\title{
ВПЛИВ ВИДУ АКТИВАЦІЇ ВОДИ НА ВЛАСТИВОСТІ ЦЕМЕНТНОГО ТІСТА ТА БЕТОНУ
}

\section{INFLUENCE OF TYPE OF WATER ACTIVATION ON PROPERTIES OF CEMENT DOUGH AND CONCRETE}

\section{Шишкіна О.О. к.т.н., доц. (Криворізький національний університет, м. Кривий Ріг) \\ Shyshkina O.O., PhD in Engineering, Associate Professor (Kryvyi Rih National University, Kryvyi Rih)}

У роботі розглянуто вплив електромагнітної, електрохімічної та фізикохімічної активачї води замімування на терміни тужавіння, нормальну густину цементного тіста, а також на міцність дрібнозернистого бетону. Наведено порівняння бетонів, які отримано при замішуванні компонентів активованою водою. Виявлено вплив активації води замішування на контракцію цементного тіста і міиність бетону.

Among the many ways to improve the preparation of concrete mix is to modify the properties of cement systems by mechanical, physical, chemical and combined effects. One of the directions of activation of the concrete mixture is the activation of its components, namely: electromagnetic, electrochemical and physics-chemical activation of mixing water. The most accessible and technological of them is the physics-chemical activation of water and aqueous solutions by certain organic substances used in ultralow concentrations, followed by their use as a mixing fluid for building mixtures. The purpose of the study was to perform a comparative assessment of the effect of electromagnetic, electrochemical and physicochemical activation of water on the properties of cement paste and fine-grained concrete. To achieve this goal, the degree of influence of electromagnetic, electrochemical and physicochemical activation of water on the contraction and hardening time of cement paste, as well as the degree of influence of electromagnetic, electrochemical and physicochemical activation of water on compressive strength of fine concrete. It is established that the type of activation of kneading water affects the hardening time of the cement paste and the normal density. The shortest hardening times are set for cement paste, which is obtained on electrochemically activated alkaline water, and the longest with the use of physics-chemical activation. At the same time, the highest strength at the lowest contraction has concrete, which is obtained on physics-chemical activated water. This concrete has the highest rate of strength. Concretes obtained on "alkaline" water, after its electro-chemical activation, have a high rate of strength formation and its value, but high contraction, which leads to cracking of concrete.

Ключові слова: активаиія, вода замішування, бетон, міџність, контракиія. Key words: activation, mixing water, concrete, strength, contraction 


\section{Постановка проблеми}

Серед численних способів вирішення вдосконалення приготування бетонної суміші $\epsilon$ модифікування властивостей цементних систем механічними, фізичними, хімічними і комбінованими впливами. Одним 3 напрямків активації бетонної суміші є активація іiї компонентів, а саме: електромагнітна (EMA) [1], електрохімічна (EXA) і фізико-хімічна [2,3] активація води замішування.

Вочевидь, найбільш доступною і технологічною 3 них $є$ фізикохімічна активація води $\mathrm{i}$ водних розчинів певними органічними речовинами, які застосовуються у надмалих концентраціях, з подальшим використанням ї в якості рідини замішування будівельних сумішей. Однак систематичні дослідження в цьому напрямку до теперішнього часу не $\epsilon$ достатніми, а порівняльний аналіз різноманітних методів активації води зовсім відсутній.

\section{Аналіз відомих досліджень і публікацій}

Відомо, що активація води замішування, а саме підвищення iii $\mathrm{pH}$ призводить до підвищення міцності цементного каменю до 20\% [4]. В той же час зменшення $\mathrm{pH}$ води замішування також призводить до підвищення міцності цементного каменю до $20 \%$ [2,3,5] не менше, ніж вода, що має підвищене значення $\mathrm{pH}$.

Дослідженнями авторів [6] показано, що замішування цементу 3 електрохімічно-активованою водою підвищує розтікання, одночасно спостерігається підвищення пластичної міцності цементного тіста в 2,2 рази і міцності цементного каменю до $70 \%$.

\section{Мета роботи}

Метою проведених досліджень було виконати порівняльну оцінку впливу EMA, EXA та фізико-хімічної активації води на властивості цементного тіста і дрібнозернистого бетону.

Для досягнення поставленої мети необхідно вирішити такі задачі:

- визначити ступінь впливу EMA, EXА та фізико-хімічної активації води на контракцію та терміни тужавіння цементного тіста;

- визначити ступінь впливу ЕМА, ЕХА та фізико-хімічної активації води на міцність при стиску дрібнозернистого бетону.

\section{Матеріали і методи}

У дослідженнях для виготовлення бетону використовували портландцемент M400 (ПрАТ «Кривий Ріг цемент»), дрібний заповнювач дніпровський річковий пісок. «Лужну» воду отримували внаслідок ЕХА на приладі ZENOR. EMA води здійснювали на спеціально виготовленому приладі, який забезпечував вплив магнітного поля на певний об'єм води. «Кислу» воду отримували додаванням олеату натрію у розчині концентрацією 0,00004\%, яка визначена, як оптимальна 3 попередніх досліджень. Компоненти бетонної суміші дозували в необхідних, відповідно до плану експерименту, кількостях, перемішували в 
лабораторному змішувачі протягом 3 хв. Отримана суміш укладалася в металеву форму-куб, який має розмір сторін 40х40х160 мм. Форму, що містить бетонну суміш, жорстко закріплювали на лабораторному вібромайданчику й ущільнювали вібрацією до повного ущільнення, яке характеризувалося припиненням осідання бетонної суміші й припиненням виділення бульбашок повітря. Після завершення укладання й ущільнення бетонної суміші у формі, відкриту поверхню зразка загладжували кельмою. Перші 24 години зразки бетону тверділи в нормальних умовах, при цьому їх до розпалубки зберігали у формах, покритих вологою тканиною. Це виключало можливість випаровування 3 них вологи в приміщенні з температурою повітря $(293 \pm 5)$ К. Через 24 години після виготовлення, зразки бетону виймали 3 форм та поміщали в камеру, яка забезпечувала на їхній поверхні нормальні умови, тобто температуру (293 $\pm 3)$ К і відносну вологість повітря $(95 \pm 5) \%$. Величини контрольованих показників якості цементного тіста та бетону визначали згідно до діючих стандартів.

\section{Результати досліджень}

Результати досліджень впливу виду активації води замішування на терміни тужавіння і нормальну густоту цементного тіста наведені в табл. 1, 3 якої видно, що вид активації води замішування впливає на терміни тужавіння цементного тіста і на нормальну густину. Так, початок і кінець тужавіння скорочуються на воді, активованій електромагнітним полем, на 10 і 15 хв, і «лужній» воді - на 20 і 35 хв. На «кислій» воді початок і кінець схоплювання сповільнюються на 20 хв.

Таблиця 1

Терміни тужавіння цементного тіста

\begin{tabular}{|c|c|c|c|c|c|}
\hline $\begin{array}{c}\text { № } \\
\text { досліду }\end{array}$ & $\begin{array}{c}\text { Вид води } \\
\text { замішування }\end{array}$ & $\mathrm{pH}$ & $\begin{array}{c}\text { ПТ, } \\
\text { хв. }\end{array}$ & КТ, хв & НГ \\
\hline 1 & Звичайна вода & 7,2 & 260 & 370 & 0,27 \\
\hline 2 & «Лужна» вода & 10,2 & 240 & 335 & 0,26 \\
\hline 3 & ЕМА вода & 9,5 & 250 & 355 & 0,26 \\
\hline 4 & «Кисла» вода & 5,8 & 280 & 390 & 0,27 \\
\hline
\end{tabular}

Примітки: ПТ - початок тужавіння, КТ - кінець тужавіння, НГ нормальна густина цементного тіста, $\mathrm{pH}$ - водневий показник.

Таким чином, визначено, що цементне тісто, приготоване на «лужній» воді, має більш короткі терміни тужавіння, ніж тісто, отримане на воді іншого методу активації або звичайній воді, а застосування «кислої» води призводить до збільшення термінів тужавіння.

Для оцінки впливу активації води замішування на процеси гідратації цементного тіста визначали величину контракції із застосуванням лінійного мікроскопу. Результати випробувань наведені на рис. 1. 


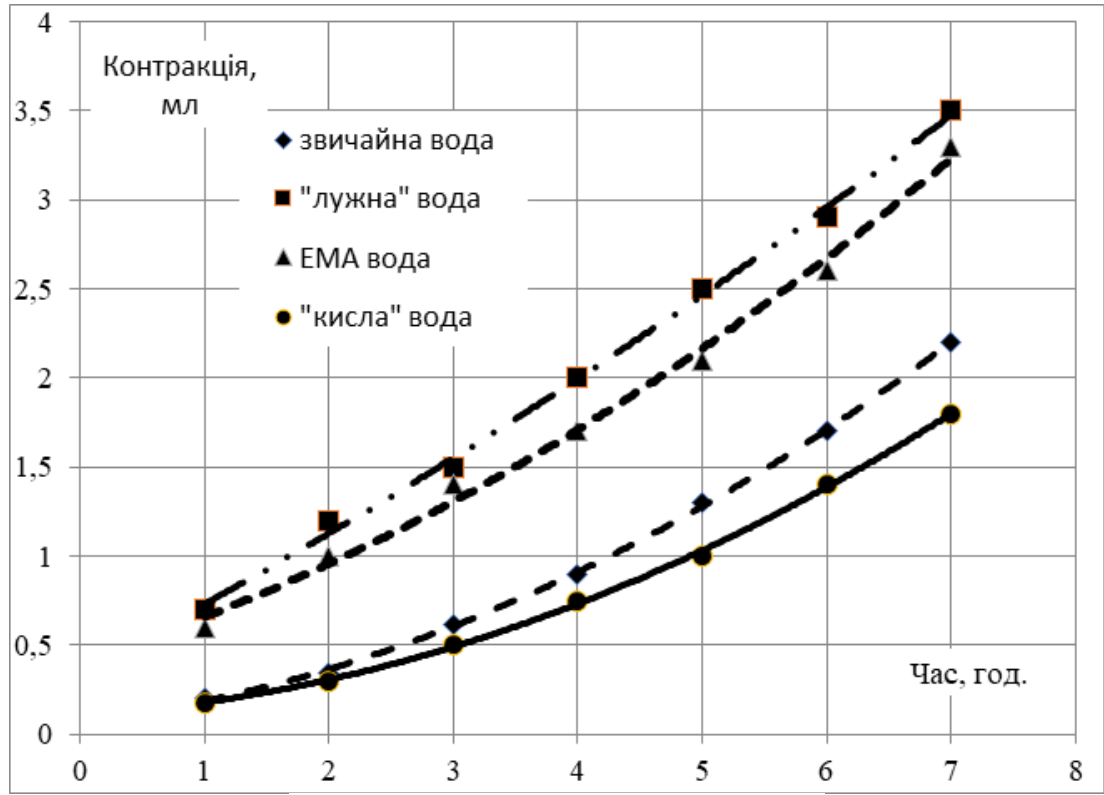

Рис. 1. Контракція цементного тіста

3 рис. 1 видно, що найбільша контракція цементного тіста спостерігається в складах, зачинених на «лужній» та ЕМА воді. Найменша контракція цементного тіста спостерігається на «кислій» воді.

Досліджено вплив активованої води замішування на міцність при згині і стиску дрібнозернистого бетону в віці 7 і 28 діб. Зразки були виконані та випробувані згідно 3 державними стандартами. Результати експерименту наведені в табл. 2 та на рис. 2.

Так, найбільше підвищення міцності спостерігається у бетонів, зачинених «кислою» водою: міцність при згині підвищується щодо контрольного на 20-51\%, а при стиску - на 18-40\%. При цьому найменше підвищення міцності розчину спостерігається в складах, зачинених ЕMA водою.

Таким чином, попередня активація води замішування дозволяє підвищити міцність цементних композицій, особливо в зразках, виконаних на «кислій» воді. 
Таблиця 2

Міцність бетону

\begin{tabular}{|c|c|c|c|c|}
\hline \multirow{2}{*}{$\begin{array}{c}\text { Вид води } \\
\text { замішування }\end{array}$} & \multicolumn{4}{|c|}{ Міцність бетону, МПа } \\
\cline { 1 - 5 } & \multicolumn{2}{|c|}{ при стиску } & \multicolumn{2}{c|}{ при вигині } \\
\cline { 2 - 5 } & 7 діб & 28 діб & 7 діб & 28 діб \\
\hline Звичайна вода & 27,9 & 33,8 & 3,33 & 5,23 \\
\hline «Лужна» вода & 30,7 & 36,5 & 3,6 & 5,9 \\
\hline ЕМА вода & 29,8 & 35,1 & 3,38 & 5,68 \\
\hline «Кисла» вода & 30,7 & 36,5 & 3,60 & 5,60 \\
\hline
\end{tabular}

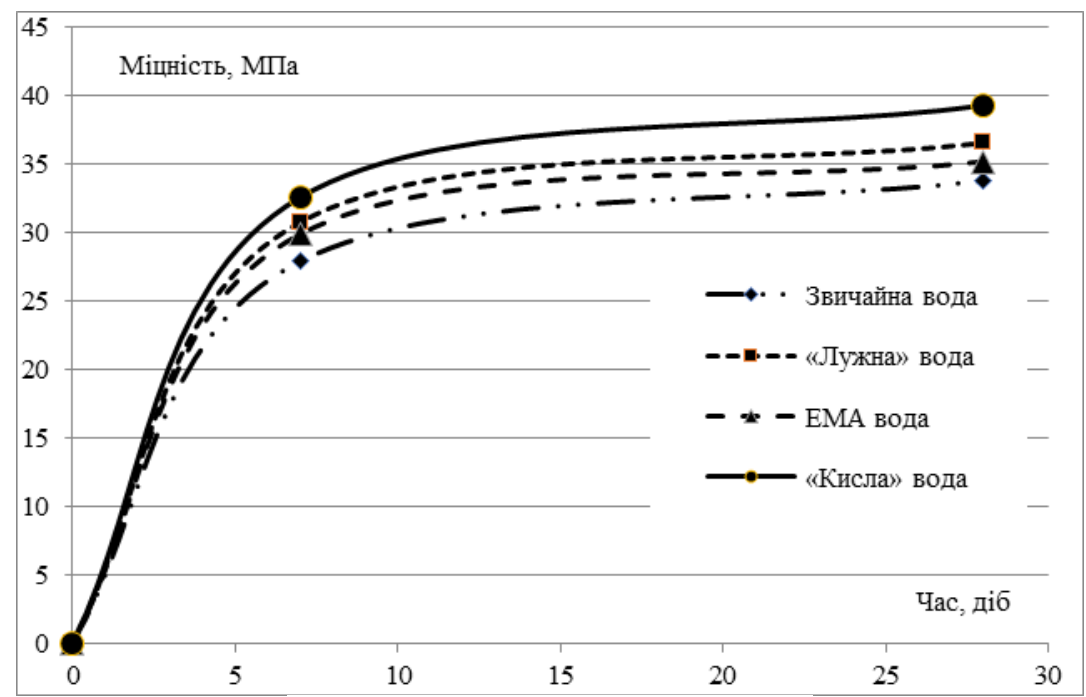

Рис. 2. Зміна міцності бетону в часі

Аналіз отриманих даних дозволяє зробити наступні висновки:

1) вода замішування, активована різними способами, впливає на властивості цементного тіста і бетону. Так, склади, отримані на лужній воді, мають коротші терміни тужавіння, в порівнянні з іншими складами;

2) кінетика контракції цементного тіста свідчить про швидшу гідратацію портландцементу, замішаного на «лужній» воді;

3) міцність при стиску і згині дрібнозернистого бетону збільшується у всіх бетонів, отриманих на активованої воді, при цьому найбільше збільшення міцності спостерігається у бетонів, приготованих на «кислій» воді. 


\section{References}

1. Makaeva A. A, PomazkIn V. A. Pro vikoristannya magnIto-aktivirovannoy vodi dlya zamishuvannya betonnih sumishey // Beton i zalizobeton, 1998, \# 3. P. 26-28.

2. Shishkina O.O. Doslidzhennya vplivu nanokatalizu na formuvannya mitsnosti reaktsiynogo poroshkovogo betonu / O.O. Shishkina, O.O. Shishkin // Vostochnoevropeyskiy zhurnal peredovyih tehnologiy. 2016. 1/6 (79). P. 55-60.

3. Staroverov V.D. Opyit promyishlennogo primeneniya nanomodifitsirovannyih betonnyih smesey / A.Yu. Kovaleva, I.U. Aubakirova, V.D. Staroverov // Vestnik grazhdanskih inzhenerov. 2008. \#3(16). P. 74-76.

4. Safronov V.M. Tsiklova magnitna aktivatsiya rIdkih seredovisch zamishuvannya z porushenoyu strukturoyu riznogo himichnogo skladu / V.M.Safronov, S.A Kugaevskiy , O.V. Rumyantseva // Vesnik TGASU. 2012. \# 3. P. 133-142.

5. Sudarev E.A. Vliyanie rastvorov kislot na protsessyi gidratatsii i tverdeniya tsementa / E.A. Sudarev, A.P. NovosYolova // Mendeleev 2012. Neorganicheskaya himiya. VI Vserossiyskaya konferentsiya molodyih uchenyih, aspirantov i studentov $\mathrm{s}$ mezhdunarodnyim uchastiem. Tezisyi dokladov.- Spb.: Izd. Solo, 2012. P. 314- 316.

6. Bazhenov Yu.M. Teoretichne obosnovanie polucheniya betonov na osnove elektrohimicheskoy i elektromagnitno-aktirovanoy vodi zatvoreniya / Yu.M.Bazhenov, V.T. FomIchov i dr. // Internet-vestnik VolgGASU 2012. Vyip. 2 (22). P. 5.

\section{Список використаної літератури}

1. Макаева А. А, Помазкін В. А. Про використання магніто-актівірованной води для замішування бетонних сумішей // Бетон і залізобетон, 1998, № 3. С. 26-28.

2. Шишкіна О.О. Дослідження впливу нанокаталізу на формування міцності реакційного порошкового бетону / О.О. Шишкіна, О.О. Шишкін // Восточноевропейский журнал передовых технологий. 2016. 1/6 (79). С. 55-60.

3. Староверов В.Д. Опыт промышленного применения наномодифицированных бетонных смесей / А.Ю. Ковалева, И.У. Аубакирова, В.Д. Староверов // Вестник гражданских инженеров. 2008. №3(16). С. 74-76.

4. Сафронов В.М. Циклова магнітна активація рідких середовищ замішування 3 порушеною структурою різного хімічного складу / В.М.Сафронов, С.А Кугаєвський, О.В. Румянцева // Весник ТГАСУ. 2012. № 3. С. 133-142.

5. Сударев Е.А. Влияние растворов кислот на процессы гидратации и твердения цемента / Е.А. Сударев, А.П. Новосёлова // Менделеев 2012. Неорганическая химия. VI Всероссийская конференция молодых ученых, аспирантов и студентов с международным участием. Тезисы докладов.- Спб.: Изд. Соло, 2012. С. 314- 316.

6. Баженов Ю.М. Теоретичне обоснование получения бетонов на основе электрохимической и электромагнитно-актированой води затворения / Ю.М.Баженов, В.Т. Фомічов и др. // Интернет-вестник ВолгГАСУ 2012. Вып. 2 (22). $5 \mathrm{c}$. 